\title{
SP-8356, a (1S)-(-)-Verbenone Derivative, Inhibits the Growth and Motility of Liver Cancer Cells by Regulating NF-KB and ERK Signaling
}

\author{
Dong Hwi Kim ${ }^{1, \dagger}$, Hyo Jeong Yong ${ }^{1, \dagger}$, Sunam Mander ${ }^{1}$, Huong Thi Nguyen ${ }^{1}$, Lan Phuong Nguyen ${ }^{1}$, \\ Hee-Kyung Park ${ }^{1}$, Hyo Kyeong Cha ${ }^{1}$, Won-Ki Kim ${ }^{1,2, *}$ and Jong-lk Hwang ${ }^{1, *}$ \\ ${ }^{1}$ Department of Biomedical Science, Korea University College of Medicine, Seoul 02841, \\ ${ }^{2}$ Department of Neuroscience, Korea University College of Medicine, Seoul 02841, Republic of Korea
}

\begin{abstract}
Liver cancer is a common tumor and currently the second leading cause of cancer-related mortality globally. Liver cancer is highly related to inflammation as more than $90 \%$ of liver cancer arises in the context of hepatic inflammation, such as hepatitis B virus and hepatitis $\mathrm{C}$ virus infection. Despite significant improvements in the therapeutic modalities for liver cancer, patient prognosis is not satisfactory due to the limited efficacy of current drug therapies in anti-metastatic activity. Therefore, developing new effective anti-cancer agents with anti-metastatic activity is important for the treatment of liver cancer. In this study, SP-8356, a verbenone derivative with anti-inflammatory activity, was investigated for its effect on the growth and migration of liver cancer cells. Our findings demonstrated that SP-8356 inhibits the proliferation of liver cancer cells by inducing apoptosis and suppressing the mobility and invasion ability of liver cancer cells. Functional studies revealed that SP-8356 inhibits the mitogen-activated protein kinase and nuclear factor-kappa B signaling pathways, which are related to cell proliferation and metastasis, resulting in the downregulation of metastasis-related genes. Moreover, using an orthotopic liver cancer model, tumor growth was significantly decreased following treatment with SP-8356. Thus, this study suggests that SP-8356 may be a potential agent for the treatment of liver cancer with multimodal regulation.
\end{abstract}

Key Words: SP-8356, Liver cancer, Proliferation, Motility, ERK, NF-кB

\section{INTRODUCTION}

Liver cancer is a frequently diagnosed tumor and currently the second leading cause of cancer-related mortality worldwide (Torre et al., 2015). Hepatocellular carcinoma (HCC) is the most common type of primary liver cancer, and the major risk factor of HCC development is viral hepatitis, such as that caused by hepatitis B virus (HBV) and hepatitis C virus (HCV) infection (El-Serag and Rudolph, 2007; Marrero and Marrero, 2007). Despite significant improvement in treatment options, including surgical resection, liver transplantation and other therapeutic modalities, the 5-year survival rate remains extremely poor due to the limited efficacy of the therapies (Bruix and Sherman, 2011; Zhu et al., 2017; Siegel et al., 2018).

As an advanced systemic therapeutic option, several multi- kinase inhibitors are available for unresectable HCC treatment. Sorafenib and lenvatinib are multi-kinase inhibitors approved by United States Food and Drug Administration as first-line treatment options for unresectable HCC. However, these systemic therapeutic options, particularly sorafenib, merely improve the survival time of HCC patients by 3-5 months and its use is occasionally restricted due to adverse side effects such as bleeding, diarrhea, and hand-foot skin reactions (Llovet et al., 2008; Je et al., 2009; Zhu et al., 2017).

Besides the limitations of the current therapies, a factor that exacerbates the prognosis of HCC patients is metastasis. Approximately one-third of HCC patients eventually develop extrahepatic metastases, with the most common sites being the lungs, lymph nodes, and bones (Poddar et al., 2017). The major pathophysiological modes for HCC metastasis are di-

\section{Open Access https://doi.org/10.4062/biomolther.2020.200}

This is an Open Access article distributed under the terms of the Creative Commons Attribution Non-Commercial License (http://creativecommons.org/licenses/by-nc/4.0/) which permits unrestricted non-commercial use, distribution, and reproduction in any medium, provided the original work is properly cited.
Received Nov 5, 2020 Revised Dec 7, 2020 Accepted Dec 10, 2020 Published Online Jan 18, 2021

\section{*Corresponding Authors}

E-mail: hjibio@korea.ac.kr (Hwang Jl),wonki@korea.ac.kr (Kim WK) Tel: +82-2-2286-1093 (Hwang الl), +82-2-2286-1094 (Kim WK) Fax: +82-2-921-4355 (Hwang Jl), +82-2-953-6095 (Kim WK) ${ }^{\dagger}$ The first two authors contributed equally to this work. 
rect extension of the tumor, hematogenous spread, and/or lymphatic invasion (Poddar et al., 2017). Because of its systemic nature and the resistance of dispersed tumor cells to existing therapeutic agents, metastasis accounts for $90 \%$ of cancer mortality (Okusaka et al., 1997; Chaffer and Weinberg, 2011; Valastyan and Weinberg, 2011). Moreover, metastatic liver cancer often leads to the recurrence of liver cancer after surgical resection (Tung-Ping Poon et al., 2000). Therefore, identifying novel and effective systemic agents with anti-metastasis activity is urgent for the treatment of HCC.

In cancer progression, inflammation has been considered an important component of the development of various cancers (Coussens and Werb, 2002). Among them, HCC is highly related to inflammation as more than $90 \%$ of HCCs arise in the context of chronic hepatic injury and inflammation (Nakagawa and Maeda, 2012). Nuclear factor-kappa B (NF-kB) is an important transcription factor that functions as a regulator of inflammation. Because inflammation predisposes cancer progression, it seems logical to speculate the link between $\mathrm{NF}-\mathrm{\kappa B}$ and cancer. NF-kB is also involved in cancer proliferation, apoptosis, metastasis, and angiogenesis (Naugler and Karin, 2008). In HCC, NF- $\mathrm{BB}$ is constitutively activated to promote tumor growth, indicating that $\mathrm{NF}-\mathrm{\kappa B}$ plays a pivotal role in HCC pathogenesis (Wang et al., 2003; Pikarsky et al., 2004; $\mathrm{Li}$ et al., 2009). Thus, the inhibition of NF-kB activation is a potential therapeutic target for liver cancer treatment.

In previous studies, essential oils containing (1S)-(-)-verbenone were identified to possess anti-inflammatory activity through the inhibition of NF-KB signaling (Choi et al., 2010; Kuo et al., 2011). Since then, a series of (1S)-(-)-verbenone derivatives has been synthesized by adding functional moieties to improve their cytoprotective effects with stronger anti-inflammatory and anti-oxidant activities (Ju et al., 2013). Given the roles of NF-kB signaling in liver cancer progression, synthesized (1S)-(-)-verbenone derivatives could be a new therapeutic agent for liver cancer.

In the present study, the effect of (1S)-(-)-verbenone derivatives on liver cancer cells was investigated. Among various (1S)-(-)-verbenone derivatives, SP-8356 demonstrated the most significant anti-proliferative effect on liver cancer cells by inducing apoptosis. In addition, SP-8356 inhibited liver cancer cell motility by regulating metastasis-related genes. Functional studies suggested that these anti-cancer activities of SP-8356 are mediated by its inhibitory effect on the mitogen-activated protein kinase (MAPK) and NF- $\mathrm{KB}$ pathways.

\section{MATERIALS AND METHODS}

\section{Reagents, culture media, and antibodies}

(1S)-(-)-verbenone derivatives were synthesized as previously reported (Ju et al., 2013). The structure of SP-8356 was already described in previous report (Pahk et al., 2019). Cell culture media were obtained from WELGENE Inc (Daegu, Korea). Human recombinant TNF- $\alpha$ was purchased from R\&D systems (Minneapolis, MN, USA), human recombinant epidermal growth factor (EGF) was purchased from Peprotech Inc. (Hamburg, Germany), and protease inhibitor cocktail was purchased from Roche (Mannheim, Germany). Antibodies against PARP, caspase-3, p-ERK1/2, and Akt were purchased from Cell Signaling Technology (Beverly, MA, USA). Antibodies against survivin, ERK1/2, p-Akt, p-Elk-1, NF-kB p65, and actin were purchased from Santa Cruz Biotechnology (Santa Cruz, CA, USA). Primers for gene cloning and materials for expression vector construction were obtained from Cosmogenetech (Seoul, Korea), and DNA sequencing was conducted by the same company. All other reagents were purchased from Sigma-Aldrich (St. Louis, MO, USA) unless otherwise stated.

\section{Cell culture}

Huh-7, Hepa1-6, Hep3B, and SK-Hep1 cells were purchased from the American Type Culture Collection (ATCC; Manassas, VA, USA). The Huh-7, Hepa1-6, and Hep3B cells were cultured in DMEM supplemented with $10 \%$ fetal bovine serum (FBS) and penicillin (100 IU/mL)/streptomycin $(100 \mu \mathrm{g} /$ $\mathrm{mL}$ ). The SK-Hep1 cells were cultured in RPMI 1640 medium supplemented with $10 \%$ fetal bovine serum (FBS) and penicillin $(100 \mathrm{IU} / \mathrm{mL}) /$ streptomycin $(100 \mu \mathrm{g} / \mathrm{mL})$. Cells were cultured at $37^{\circ} \mathrm{C}$ in a humidified chamber containing $5 \% \mathrm{CO}_{2}$.

\section{Cell growth assay}

Huh-7, Hep3B, SK-Hep1 (3,000 cells/well), and Hepa1-6 (1,000 cells/well) cells were seeded into 96-well plates and treated with various concentrations of (1S)-(-)-verbenone derivatives for the indicated times in complete culture medium. Cell growth was measured using a Cell Counting Kit-8 (CCK8) kit from Dojindo Molecular Technologies, Inc. (Rockville, $\mathrm{MD}, \mathrm{USA}$ ) following the manufacturer's instructions. Cells were incubated with $10 \mu \mathrm{L}$ of CCK-8 solution for $2 \mathrm{~h}$, and the absorbance of each well was measured at $450 \mathrm{~nm}$ using a microplate reader, SpectraMax iD3 (Molecualr Devices, LLC, San Jose, CA, USA).

\section{Lactate dehydrogenase (LDH) assay}

Cell cytotoxicity was quantitatively assessed by measuring $\mathrm{LDH}$ released from plasma membrane-damaged cells using a cytotoxicity detection kit according to the manufacturer's instructions (Takara Bio Company, Shiga, Japan). Huh-7, Hepa1-6, and Hep3B cells were seeded in a 96-well plate in DMEM with $10 \%$ FBS and incubated for $24 \mathrm{~h}$. Next, cells were incubated with $200 \mu \mathrm{L}$ serum-free DMEM medium with SP8356 for $24 \mathrm{~h}$ and $48 \mathrm{~h}$. Cells treated with vehicle (DMSO) were used as a negative control. Some of the vehicle-treated cells were lysed with $1 \%$ Triton X-100 buffer and used as a positive or high control. Microtiter plates were centrifuged at $250 \times \mathrm{g}$ for $10 \mathrm{~min} ; 100 \mu \mathrm{L}$ of supernatant was transferred to another 96-well plate with the addition of $100 \mu \mathrm{L}$ of reaction mixtures. After 30 min of incubation at room temperature, absorbance was measured at $490 \mathrm{~nm}$ using a microplate reader (SpectraMax iD3, Molecualr Devices, LLC). The relative activity of $\mathrm{LDH}(\%)$ was calculated as $\{([\mathrm{A}]$ sample-[A]negative control $) /([\mathrm{A}]$ high control-[A]negative control $)\} \times 100$.

\section{Western blot analysis and immunoprecipitation}

Cells were lysed in RIPA buffer [50 mM Tris- $\mathrm{HCl}, \mathrm{pH} 7.5$, $150 \mathrm{mM} \mathrm{NaCl}, 1 \%$ Triton $\mathrm{X}-100,0.5 \%$ sodium deoxycholate $(\mathrm{w} / \mathrm{v})$, and $0.05 \%$ sodium dodecyl sulfate (SDS) (w/v)] containing protease inhibitor. The lysates were centrifuged at 15,000 $\mathrm{rpm}$ at $4^{\circ} \mathrm{C}$ for $15 \mathrm{~min}$. Protein concentrations of the clarified lysates were determined using a Bradford protein assay kit (Bio-Rad, Hercules, CA, USA). Next, $20 \mu \mathrm{g}$ of cell lysates denatured with sodium dodecyl sulfate (SDS) sample buffer was separated by polyacrylamide gel electrophoresis. Proteins were transferred to nitrocellulose membranes and probed with 
the relevant antibodies. The signals were then detected using an ECL assay kit (GE Healthcare, Chicago, IL, USA).

HEK293 cells cultured in DMEM with 10\% FBS were transfected with the HA-importin $\alpha 5$ plasmid, treated with tumor necrosis factor (TNF)- $\alpha$, and subjected to immunoprecipitation with anti-HA antibody-conjugated agarose. The precipitates were subjected to western blotting with anti-p65 antibodies (Santa Cruz Biotechnology).

\section{Luciferase assay}

Huh-7 cells were seeded into 24-well plates and then transfected with plasmids containing the serum response element (SRE)-luc and NF-kB-luc reporter genes. Cells cultured in serum-free DMEM media for $18 \mathrm{~h}$ were treated with different concentrations of SP-8356 for $30 \mathrm{~min}$ and then treated with $10 \%$ serum, $100 \mathrm{ng} / \mathrm{mL}$ of epidermal growth factor (EGF), 1 $\mu \mathrm{M}$ PMA (phorbol 12-myristate 13-acetate), and $10 \mathrm{ng} / \mathrm{mL}$ TNF- $\alpha$ as a stimulant. After $6 \mathrm{~h}$, cells were washed with phosphate-buffered saline (PBS) and solubilized with lysis buffer. The luciferase activity of the cell extracts was determined using the standard luciferase assay system from BioTek Instruments, Inc (Winooski, VT, USA).

\section{Wound healing assay}

Huh- 7 and Hepa1- 6 cells $\left(5 \times 10^{5}\right.$ cells/well) were seeded into 6-well plates. Confluent monolayers were manually scratched with a pipette tip and washed with PBS to remove the cell debris. Cells were incubated in DMEM media with different concentrations of SP-8356, and the scratch area was photographed at the indicated times. The area between two cell edges was analyzed using Image $\mathrm{J}$ software (National Institutes of Health, Bethesda, MD, USA). The percentage of wound closure was calculated as follows: [(area of original wound-area of remaining wound)/(area of original wound)] $\times 100$.

\section{Invasion assay}

For the invasion assay, the upper chambers of Transwell inserts ( $8-\mu \mathrm{m}$ pore size; Corning, NY, USA) were coated with $20 \mu \mathrm{L}$ of 1:6 diluted Matrigel (Invitrogen, Carlsbad, CA, USA) and allowed to solidify in an incubator. Next, $2 \times 10^{4}$ Huh- 7 cells and $1 \times 10^{4}$ Hepa1- 6 cells in serum-free media were placed into the upper chambers of the inserts and then treated with SP8356. The lower wells were filled with DMEM containing $10 \%$ FBS. Cells were incubated at $37^{\circ} \mathrm{C}$ in a humidified chamber containing $5 \% \mathrm{CO}_{2}$ for $18 \mathrm{~h}$. The inserts were washed in PBS, and the cells in the upper chamber that had not invaded were removed with a cotton swab. The membranes were fixed in $4 \%$ paraformaldehyde solution and stained with Hemacolor Rapid staining of blood smear (Merck, Darmstadt, Germany); cells that had invaded were counted under a microscope.

\section{Immunocytochemistry}

Huh-7 cells were grown on poly-L-lysine-coated glass coverslips in 24-well plates. After $24 \mathrm{~h}$, the cells were incubated in serum-free DMEM for $18 \mathrm{~h}$, treated with $20 \mu \mathrm{M} \mathrm{SP}-8356$ for 30 $\mathrm{min}$, and then treated with $10 \mathrm{ng} / \mathrm{mL}$ of TNF- $\alpha$ or $1 \mu \mathrm{M}$ PMA for $30 \mathrm{~min}$. Cells were fixed with $4 \%$ paraformaldehyde in PBS for 10 min, permeabilized with PBS containing $0.1 \%$ Triton X-100 (PBST) for $10 \mathrm{~min}$, and then blocked with $3 \%$ bovine serum albumin in PBST for 30 min. Next, the cells were incubated with anti-p65 antibodies in PBST containing 3\% bovine serum albumin overnight at $4^{\circ} \mathrm{C}$. The coverslips were washed and incubated with fluorescein isothiocyanate (FITC)-conjugated anti-mouse IgG for $1 \mathrm{~h}$. The fluorescent images were viewed using a Leica TCS SP5 laser scanning microscope (Leica, Wetzlar, Germany).

\section{Reverse transcription-quantitative polymerase chain reaction (RT-qPCR)}

Total RNA was extracted using TRIzol (Invitrogen) according to the manufacturer's instructions. cDNA was generated using reverse transcriptase (Promega, Madison, WI, USA) for $2 \mu \mathrm{g}$ of extracted total RNA, and qPCR was performed using iQTM SYBR Green Supermixture and the iCycler PCR Thermocycler (Bio-Rad) with gene-specific primer sets designed using Beacon Designer version 2.1 (Premier Biosoft International, Palo Alto, CA, USA) as follows: urokinase-type plasminogen activator (UPA; 5'-ttgctcaccacaacgacatt-3' and 5'-ggcaggcagatggtctgtat-3'), plasminogen activator inhibitor (PAl; 5'-actggaaaggcaacatga-3' and $5^{\prime}$-ctctaggggcttcctgaggt-3'), vascular endothelial growth factor (VEGF)-A (5'-ggagtccaacatcaccat-3' and 5'-cttgtcttgctctatcttctt-3'), VEGF-C (5'-tcaaggacagaagagactat-3' and $5^{\prime}$-ctccactcattatcaatactttc- $3^{\prime}$ ), matrix metalloproteinase (MMP)7 (5'-gctgacatcatgattggcttt-3' and 5'-tctcctccgagacctgtcc-3'), MMP-9 (5'-atccggcacctctatggtc-3' and 5'-ctgaggggtggacagtgg- $\left.3^{\prime}\right)$, and $\beta$-actin (5'-gcgagaagatgacccaga-3' and 5 '-atcacgatgccagtggta- $\left.3^{\prime}\right)$. The mRNA level of each gene was normalized to that of $\beta$-actin.

\section{Orthotopic xenograft model and in vivo imaging}

All mice were housed in a temperature-controlled $\left(22-23^{\circ} \mathrm{C}\right)$ facility with a specific pathogen-free barrier under a 12-h light/ dark photoperiod (lights on at 8:00 am). Mice were allowed standard mouse chow and water ad libitum. All animal experiments and procedures were performed in accordance with the guidelines and regulations of the Institutional Animal Care and Use Committee (IACUC) at Korea University (KOREA20160153-C4).

Four- to six-week-old male NOD/SCID mice were purchased from KOATECH (Pyeongtek, Korea). Huh-7 cells $\left(2 \times 10^{6}\right)$ were injected into the left liver lobe of NOD/SCID mice. After 1 day, the mice were randomized into two groups comprised of five mice each. The experimental group was treated with SP$8356(30 \mathrm{mg} / \mathrm{kg})$ every day by intraperitoneal injections until the end of the experiment and the control group was similarly treated with vehicle (saline). Body weight was measured every other day. After 40 days, the mice were intraperitoneally injected with luciferin and subjected to in vivo live imaging using NightOWL II LB 983 (Berthold Technologies, Bad Wildbad, Germany). After imaging, the mice were sacrificed and their livers were post-fixed with $4 \%$ paraformaldehyde. The nodule number and size in the isolated livers were assessed visually.

\section{Statistical analysis}

All statistical analysis was performed using PRISM5 software (GraphPad, La Jolla, CA, USA). The group means were presented as means \pm standard deviation (SD) and statistical significance was evaluated using Student's $t$ tests and/or oneway or two-way analysis of variance (ANOVA) with Bonferroni post hoc tests. A $p$-value less than 0.05 was considered statistically significant. All experiments were performed in triplicate unless otherwise indicated. 


\section{RESULTS}

\section{SP-8356 inhibits the growth of liver cancer cells}

Based on the various effects of (1S)-(-)-verbenone, such as anti-inflammatory, anti-oxidant, and anti-proliferation, we designed and synthesized (1S)-(-)-verbenone derivatives to investigate their anti-cancer effects on liver cancer cells. Among these derivatives, the S form of SP-8356 significantly inhibited the growth of Huh-7 cells in a time- and dose-dependent manner, while the $R$ form of the molecule had no effect (Fig. 1A). Therefore, in further experiments, the S form of SP-8356 was used. Because SP-8356 showed the most significant growth inhibitory effect, we focused only on SP-8356 in subsequent experiments. The effect of SP-8356 was further investigated in several liver cancer cell lines, and its growth inhibitory activity was observed in all tested cell lines, Hepa1-6, Hep3B and SKHep1, with different efficiencies (Fig. 1B).

\section{SP-8356 shows mild cytotoxicity by inducing apoptosis in liver cancer cells}

Because the growth inhibitory effect of SP-8356 may be related to the cytotoxic activity of the molecule to liver cancer cells, LDH assays were performed to measure cell death due to SP-8356. The LDH activities in the cells were slightly increased by SP-8356 in a dose-dependent manner. Maximum LDH activities were observed at $48 \mathrm{~h}$ to be $21.83 \%$, $31.56 \%$, and $8.77 \%$ with $20 \mu \mathrm{M}$ SP-8356 in Huh-7, Hepa1-6, and Hep3B cells, respectively (Fig. 2A). In particular, the LDH activities in Huh-7 and Hep3B did not change over time as they were similar at both 24 and $48 \mathrm{~h}$. These results may be ascribed to mild cytotoxicity of SP-8356 in these liver cancer cells.

To explore the mechanisms underlying the cytotoxic effects of SP-8356, protein extracts of affected cells were subjected to western blotting with antibodies against death- or survivalrelated proteins. Caspase activation was examined because it is a hallmark of apoptosis (Ola et al., 2011). Cleaved caspase- 3 was detected in Hepa1-6 cells treated with $20 \mu \mathrm{M} \mathrm{SP}$ 8356. Although cleaved caspase- 3 was not detected in Huh-7 and Hep3B cells, pro-caspase- 3 was decreased, indicating that pro-caspase- 3 was activated in these cells. Additionally, the cleavage of PARP, another apoptotic marker, was notably detected in all cells, even with $15-\mu \mathrm{M}$ SP-8356 treatment in Huh-7 cells. Expression of survivin, a member of the apoptosis-inhibitory family, was decreased by SP-8356 in all cell lines (Fig. 2B). Taken together, these results suggest that the anti-proliferative effect of SP-8356 is likely correlated with the cytotoxic activities of SP-8356.

\section{SP-8356 suppresses the migration and invasion of liver cancer cells}

Because metastasis accounts for most liver cancer-related deaths, the effect of SP-8356 on cell motility was determined using wound healing migration assays (Okusaka et al., 1997; Chaffer and Weinberg, 2011; Uchino et al., 2011; Valastyan and Weinberg, 2011). SP-8356 significantly reduced cell migration at $15 \mu \mathrm{M}$ and $20 \mu \mathrm{M}$ in Huh-7 cells and $20 \mu \mathrm{M}$ in Hepa1-6 cells compared with of control-treated cells (Fig. 3A).

The effect of SP-8356 on cell invasiveness was investigated using a Matrigel invasion assay. Both Huh-7 and Hepa16 cell lines penetrated the matrix toward serum stimulation. The number of invading cells decreased in a dose-dependent
A
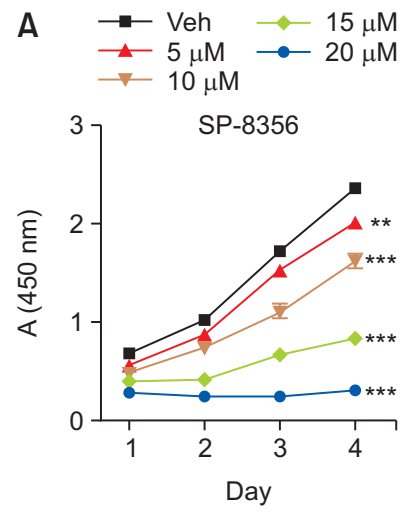

$\begin{aligned} \text { B } & \rightarrow \text { Veh } \multimap 15 \mu \mathrm{M} \\ & \multimap 5 \mu \mathrm{M} \longrightarrow 20 \mu \mathrm{M} \\ & \multimap 10 \mu \mathrm{M}\end{aligned}$
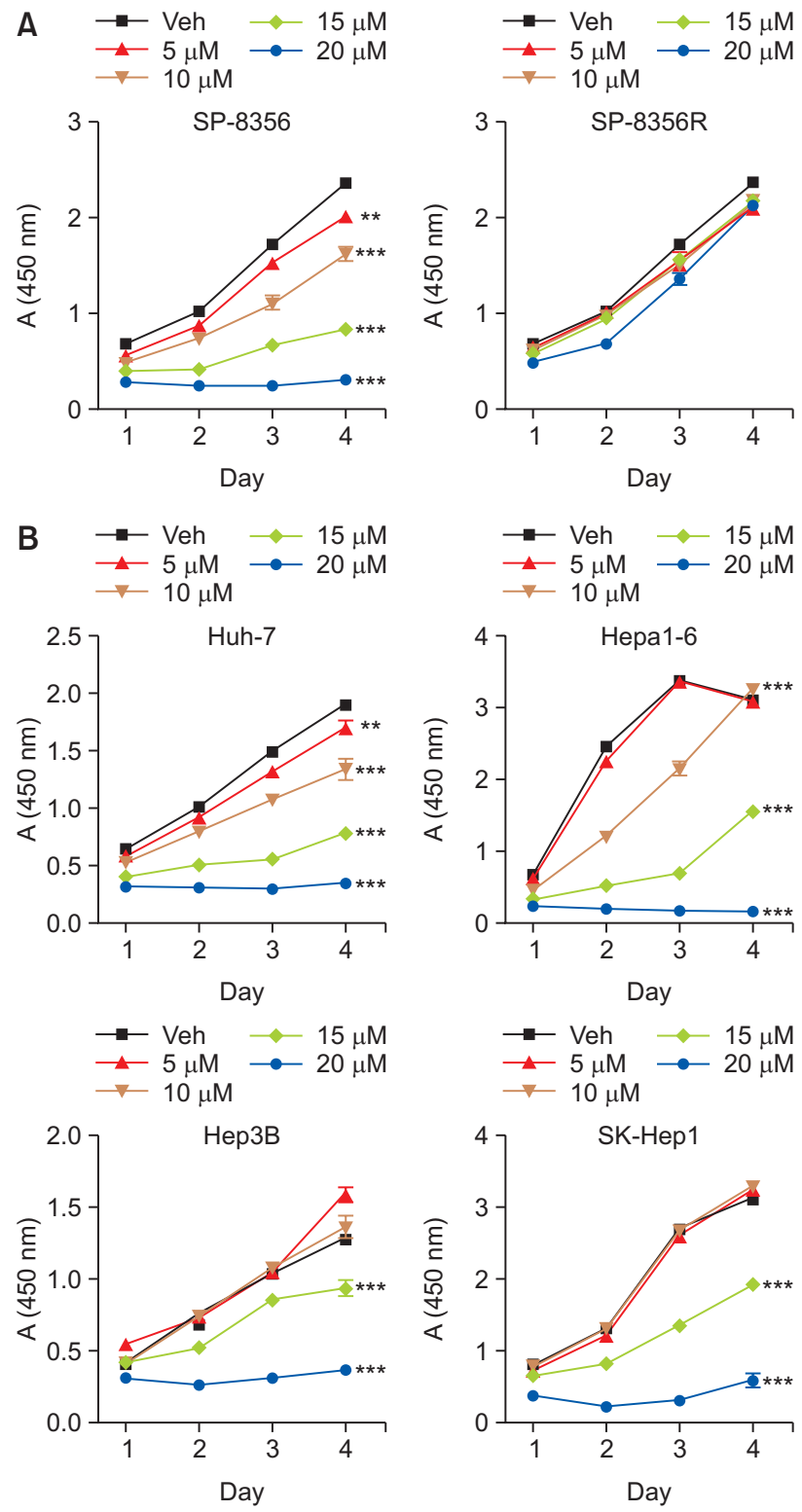

Fig. 1. SP-8356 inhibits proliferation of liver cancer cells. (A) The effect of enantiomers of synthesized (1S)-(-)-verbenone derivative SP-8356 on Huh-7 cell proliferation was investigated using the CCK-8 assay. The cells were treated with various doses of verbenone derivatives for $24,48,72$, and $96 \mathrm{~h}$. For SP-8356 panel; $\mathrm{F}(4,30)=434.78, p<0.0001$ across SP-8356 concentration. (B) The effect of SP-8356 on different liver cancer cells. For Huh-7 panel; $F(4,30)=434.78, p<0.0001$, Hepa1 -6 panel; $F(3,30)=1508.20$, $p<0.0001$, Hep3B panel; $F(3,30)=394.64, p<0.0001$ and SK-Hep1; $\mathrm{F}(3,30)=3464.87, p<0.0001$ across SP-8356 concentration. All values are shown as means $\pm \mathrm{SD} .{ }^{* *} p<0.01,{ }^{* * *} p<0.001$ versus Veh by two-way analysis of variance (ANOVA) with Bonferroni post hoc test.

manner in response to SP-8356 treatment; in particular, invading Huh-7 cells were not detected following 20- $\mu \mathrm{M} \mathrm{SP-8356}$ treatment (Fig. 3B). Thus, SP-8356 likely exerts a suppressive effect on the migration and invasion of liver cancer cells. Hep3B cells were excluded in the cell motility assay because they are not invasive. 
A

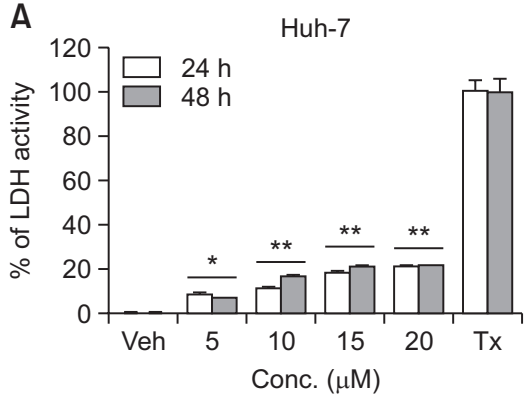

B

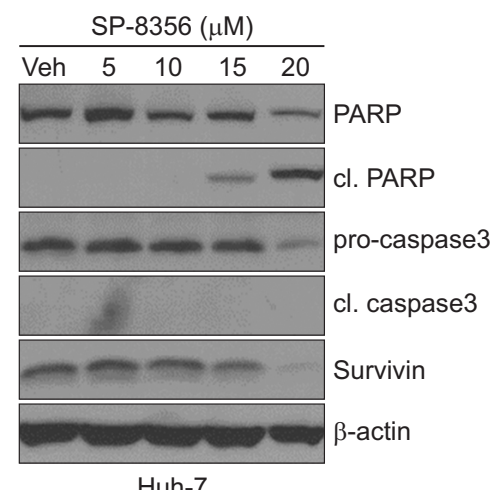

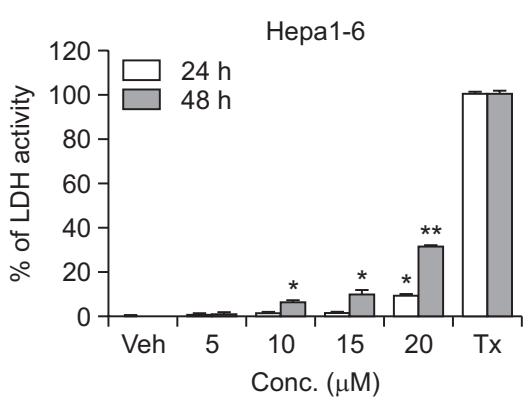

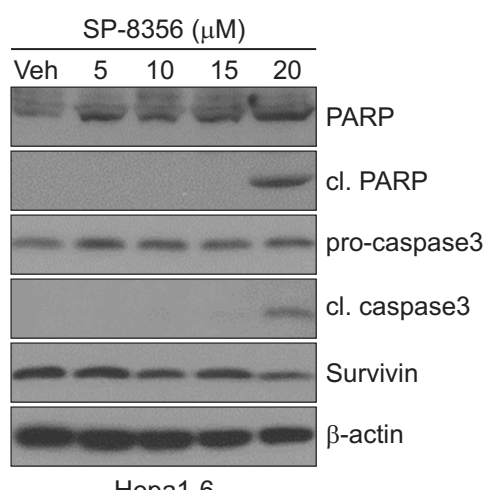

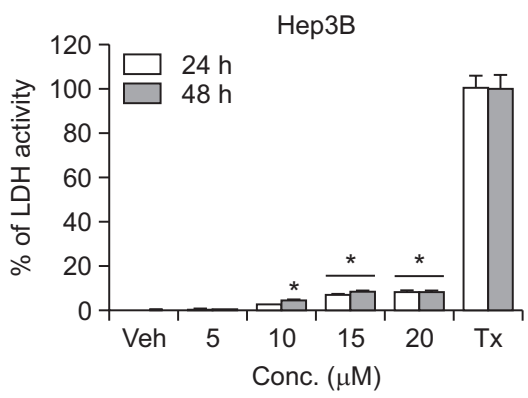

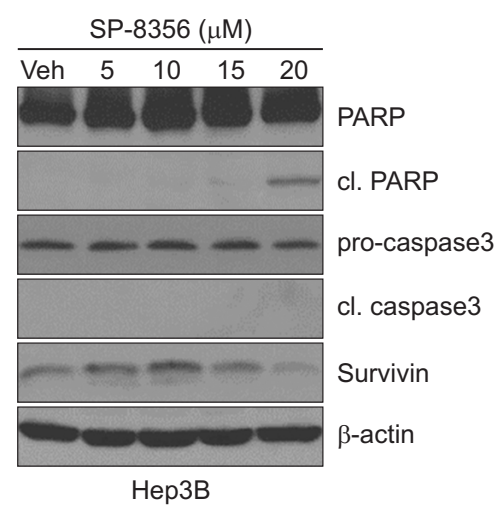

Fig. 2. SP-8356 has mild cytotoxicity due to apoptosis induction in liver cancer cells. (A) Cell death in liver cancer cells was investigated using the LDH assay. Huh-7, Hepa1-6, and Hep3B cells were treated with vehicle or SP-8356 for $24 \mathrm{~h}$ and $48 \mathrm{~h}$. As a positive control, the cells were lysed with $1 \%$ Triton X-100. (B) Effects of SP-8356 on apoptosis. Cells were incubated with different doses of SP-8356 for $24 \mathrm{~h}$. Equal amounts of cell extracts were separated by $10 \%$ SDS-PAGE, electro-transferred onto nitrocellulose membranes, and analyzed by western blotting using appropriate antibodies. $\beta$-actin was used as a loading control. All values are shown as means \pm SD. ${ }^{*} p<0.05$, ${ }^{* *} p<0.01$ versus Vehicle by Student's $t$-test.

\section{SP-8356 inhibits the MAPK pathway via blocking the nuclear translocation of $p$-ERK $1 / 2$}

Following analysis of the anti-cancer activities of SP-8356, the effects of the reagent on signaling molecules were examined. Dysregulation of the MAPK and PI3K/Akt signaling pathways commonly occur in liver cancer; the sustained activation of these pathways facilitates liver cancer proliferation and survival (Liu et al., 2009; Min et al., 2011). SRE-dependent luciferase activity by serum, EGF, and PMA (a protein kinase C activator) was significantly reduced by SP-8356 treatment in Huh-7 cells (Fig. 4A).

To understand which molecular mechanism is involved when SP-8356 suppresses SRE activity in response to the tested stimulants, the phosphorylation of ERK1/2 and Akt was investigated. Although the levels of phosphorylated ERK1/2 and Akt remained unchanged in the presence of SP-8356, it inhibited the phosphorylation of Elk-1, a downstream target of $\mathrm{p}$ ERK1/2, which later forms a temporal complex with SRE (Fig. 4B). Because the nuclear translocation of ERK $1 / 2$ is needed to phosphorylate nuclear Elk-1 (Flores and Seger, 2013), it was hypothesized that SP-8356 may inhibit the nuclear translocation of phosphorylated ERK1/2. To test this hypothesis, we compared the presence of phosphorylated ERK $1 / 2$ in the cytoplasm and nucleus. In the cytoplasm, the degree of phosphorylated ERK $1 / 2$ was increased when the cells were treated with SP-8356 and EGF compared with that in the cells treated with EGF only (Fig. 4C). Phosphorylated ERK1/2 was notably increased in the nucleus of EGF-treated cells. However, nuclear phosphorylated ERK1/2 was unchanged in the presence of SP-8356, suggesting an inhibitory effect of SP-8356 on p-ERK $1 / 2$ nuclear translocation. Taken together, these data suggest that SP-8356 regulates the MAPK pathway by inhibiting the nuclear translocation of $p$-ERK1/2.

\section{SP-8356 suppresses NF-kB activation by inhibiting the nuclear translocation of $\mathrm{p} 65$}

Activation of NF-kB is important for cancer progression and metastasis, and its inhibition contributes to cancer suppression (Pikarsky et al., 2004; Naugler and Karin, 2008; Wu et al., 2009). Because (1S)-(-)-verbenone regulates NF-kB activation under certain conditions, including inflammation (Choi et al., 2010; Kuo et al., 2011), the effect of SP-8356 on NF$\kappa B$ signaling was examined in Huh-7 cells. TNF- $\alpha$-induced NF-kB-dependent luciferase expression was significantly decreased by SP-8356 (Fig. 5A). Huh-7 cells were treated with PMA because some protein kinase $\mathrm{C}$ subgroups can activate IKK, an upstream kinase of NF-kB activation. Interestingly, SP-8356 also suppressed PMA-induced NF-kB transcriptional activation (Fig. 5B).

SP-8356 reduced the basal transcriptional activity of NF-KB without stimulation. In unstimulated cells, NF-kB is sequestered in the cytoplasm bound to inhibitor of kappa $B(\mathrm{I} \mathrm{KB})$. After exposure to stimuli such as TNF- $\alpha$, PMA, and lipopolysaccharide, I $\mathrm{KB}$ is phosphorylated by IKB kinase (IKK), followed by ubiquitination and degradation that lead to the nuclear translocation of the RelA/p65 subunit of NF-kB (Hoesel and Schmid, 2013). 
A
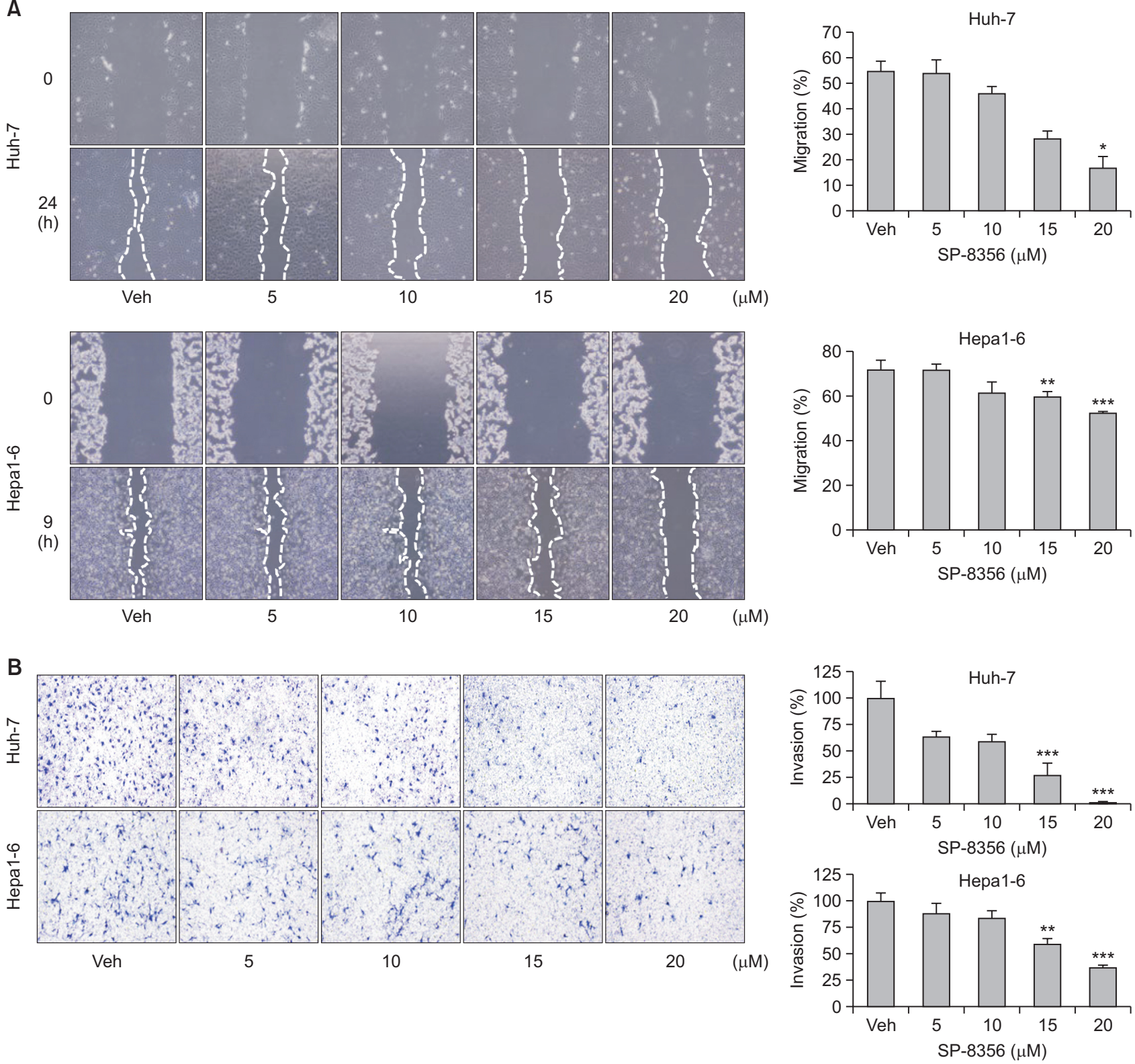

Fig. 3. SP-8356 downregulates migration and invasion of liver cancer cells. (A) Wound healing assay. Huh-7 and Hepa1-6 cells were grown to confluence and scratched with a pipette tip. The monolayer was captured under a microscope. After incubation with the indicated doses of SP-8356, the images were captured at $24 \mathrm{~h}$ in Huh-7 cells and $9 \mathrm{~h}$ in Hepa1-6 cells. Representative microscopic images are shown; the right panels show the percentages of wound closure in the various treatment groups. For Huh-7 panel, $F(4,15)=16.82, p<0.0001$ and Hepa1-6 panel, $F(4,15)=5.520, p<0.0062$ across SP-8356 concentration. (B) Invasion assay. Huh-7 and Hepa1-6 cells treated with SP8356 were seeded into Matrigel-coated Transwell chambers and incubated for $18 \mathrm{~h}$. The lower membrane surface to which cells migrated were fixed and stained. Representative images are shown; the number of invading cells was calculated as a percentage of invasion. For Huh-7 panel, $F(4,15)=14.75, p<0.0001$ and Hepa1-6 panel, $F(4,15)=13.63, p<0.0001$ across SP-8356 concentration. All values are shown as means \pm SD. ${ }^{*} p<0.05,{ }^{* *} p<0.01,{ }^{* * *} p<0.001$ versus Vehicle by one-way analysis of variance (ANOVA) with Bonferroni post hoc test.

To investigate whether SP-8356 inhibits the nuclear translocation of p65, immunocytochemistry was performed. Before TNF- $\alpha$ and PMA treatment, p65 was mainly located in the cytoplasm; after TNF- $\alpha$ and PMA treatment, p65 was translocated to the nucleus. However, $20-\mu \mathrm{M} \mathrm{SP}-8356$ pretreatment suppressed the nuclear translocation of 065 by TNF- $\alpha$ and PMA (Fig. 5C). The quantitative data of the nuclear translocation showed that the percentage of nuclear p65 induced by
TNF- $\alpha$ or PMA was significantly decreased by SP-8356 (Fig. 5D). These results indicate that SP-8356 inhibits NF-kB activation by blocking the nuclear translocation of $\mathrm{p} 65$.

Because the nuclear translocation of p65 was carried out by importins, blockade of the interaction between free p65 and importin may be the inhibitory mechanism of SP-8356. This idea was confirmed by immunoprecipitation and subsequent western blotting with cells expressing HA-importin $\alpha 5$; p65 

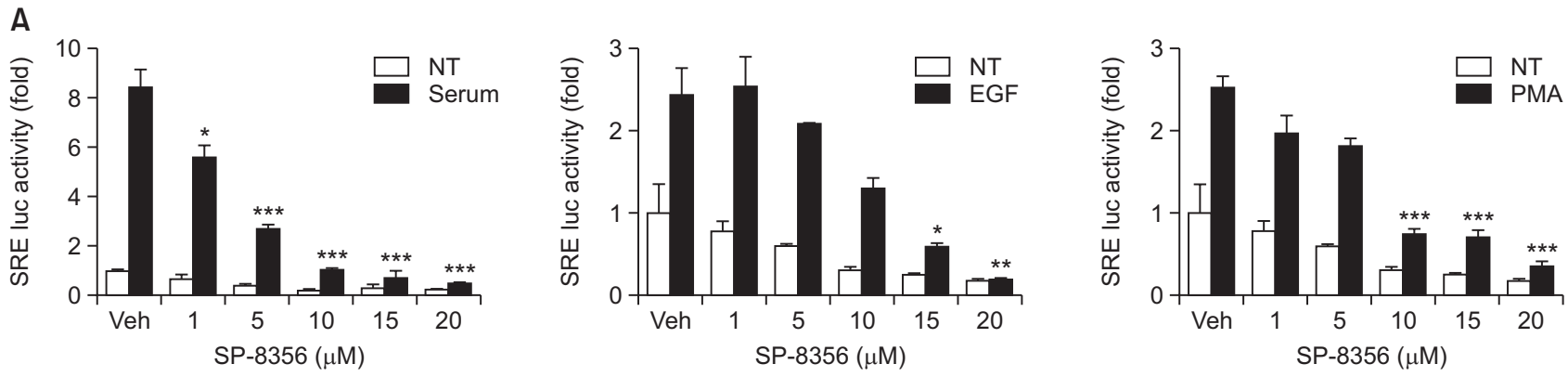

B
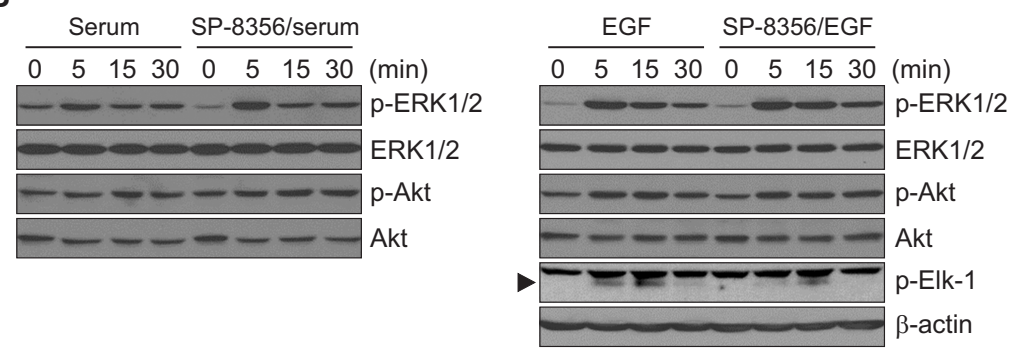

C

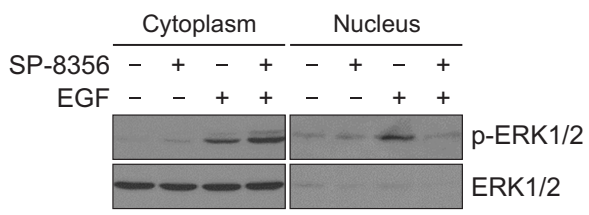

Fig. 4. SP-8356 suppresses the MAPK signaling pathway in Huh-7 cells. (A) SP-8356 reduces serum-, EGF-, and PMA-stimulated SRE activity. Huh-7 cells were transfected with plasmids containing an SRE-luciferase reporter gene construct. After $18 \mathrm{~h}$ of serum starvation, cells were treated with different doses of SP-8356 before stimulation with $10 \% \mathrm{FBS}, 100 \mathrm{ng} / \mathrm{mL}$ EGF, or $1 \mu \mathrm{M}$ PMA. Cells were lysed and analyzed in luciferase activity assays. For first panel, $\mathrm{F}(5,6)=64.71, p<0.0001$ across SP-8356 concentration within serum treated group, second panel, $\mathrm{F}(5,6)=21.35, p<0.0009$ across SP-8356 concentration within EGF treated group and third panel, $F(5,6)=46.51, p<0.0001$ across SP-8356 concentration within PMA treated group. (B) To investigate the effect of SP-8356 on the MAPK pathway, after $18 \mathrm{~h}$ of starvation, Huh-7 cells were treated with $20 \mu \mathrm{M}$ SP-8356 for $30 \mathrm{~min}$ before stimulation with $10 \% \mathrm{FBS}$ and $100 \mathrm{ng} / \mathrm{mL}$ of EGF for the indicated time points. Cell lysates were subjected to western blotting. Phosphorylation of ERK1/2, Akt, and Elk-1 was determined. (C) To examine the localization of p-ERK1/2, after $18 \mathrm{~h}$ of starvation, Huh-7 cells were treated with $20 \mu \mathrm{M} \mathrm{SP}-8356$ for 30 min and then treated with $100 \mathrm{ng} /$ $\mathrm{mL}$ of EGF for $15 \mathrm{~min}$. Cytoplasmic and nuclear protein extracts were subjected to western blotting. All values are shown as means \pm SD. ${ }^{*} p<0.05,{ }^{* *} p<0.01,{ }^{* * *} p<0.001$ versus Veh by one-way analysis of variance (ANOVA) with Bonferroni post hoc test.

was not detected in the anti-HA antibody-mediated immunoprecipitation of SP-8356-treated cells (Fig. 5E).

\section{SP-8356 regulates the expression of metastasis-related genes}

The invasive and metastatic properties of cancer cells are acquired by gene expression related to extracellular matrix degradation and new blood vessel formation around the tumor (Valastyan and Weinberg, 2011). Thus, the effect of SP-8356 on the expression of genes influencing cell adhesion, local invasion, and angiogenesis, most of which are targets of NF$\kappa B$, was examined. The mRNA levels of UPA, VEGF-A, and VEGF-C were decreased in Huh-7 cells treated with SP-8356 in a dose-dependent manner, whereas that of PAI was significantly increased compared with that in control cells (Fig. 6A). The mRNA levels of MMP-7 and MMP-9 were also reduced by SP-8356 treatment in cells stimulated with TNF- $\alpha$ (Fig. 6B). These results suggest that SP-8356 inhibits the migration and invasion of liver cancer cells by regulating the metastasis-related genes induced by NF-kB.

\section{Anti-proliferative effect of SP-8356 in a xenograft model}

To investigate the in vivo correlation of the cellular effects of SP-8356, we established a xenograft model by implanting Huh-7 cells expressing luciferase in the liver of SCID mice and then treated the mice with SP-8356 or saline every day. Forty days later, the mice were injected intraperitoneally with luciferin and subjected to in vivo live imaging. Average body weight was similar in both groups (Fig. 7A). The luminescence signals in saline-treated mice were much stronger than those in the SP-8356-treated group (Fig. 7B). After perfusion with PBS and fixing with $4 \%$ paraformaldehyde, nodule numbers and size in the isolated livers were higher in the control group than in the SP-8356-treated group, implying that SP-8356 inhibited Huh-7 growth in the liver (Fig. 7C). Unfortunately, we did not observe micrometastasis of the cells in the liver or metastasis into other organs, such as the lung, brain, and other peritoneal regions, in histological analysis. The cause may be the low motility of Huh-7 cells in the in vivo model.

\section{DISCUSSION}

Most HCC cases are closely associated with NF-кB-related chronic inflammation, and a significant portion of liver cancer patients eventually develop extrahepatic metastasis (Uka et al., 2007; Singh et al., 2018). Treatment of unresectable HCC largely relies on systemic therapeutics, such as multi-kinase inhibitors; however, current systemic treatment options do not produce satisfactory results. (Wang et al., 2003; Pikarsky et al., 2004; Li et al., 2009; Nakagawa and Maeda, 2012; Zhu et al., 2017). Thus, a new anti-cancer agent is needed for effective anti-inflammatory and anti-metastasis activities. In this study, some of the synthesized (1S)-(-)-verbenone derivatives with anti-inflammatory activity (Ju et al., 2013) were screened for growth inhibition of Huh-7 liver cancer cells. One of the de- 


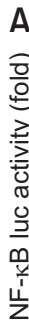
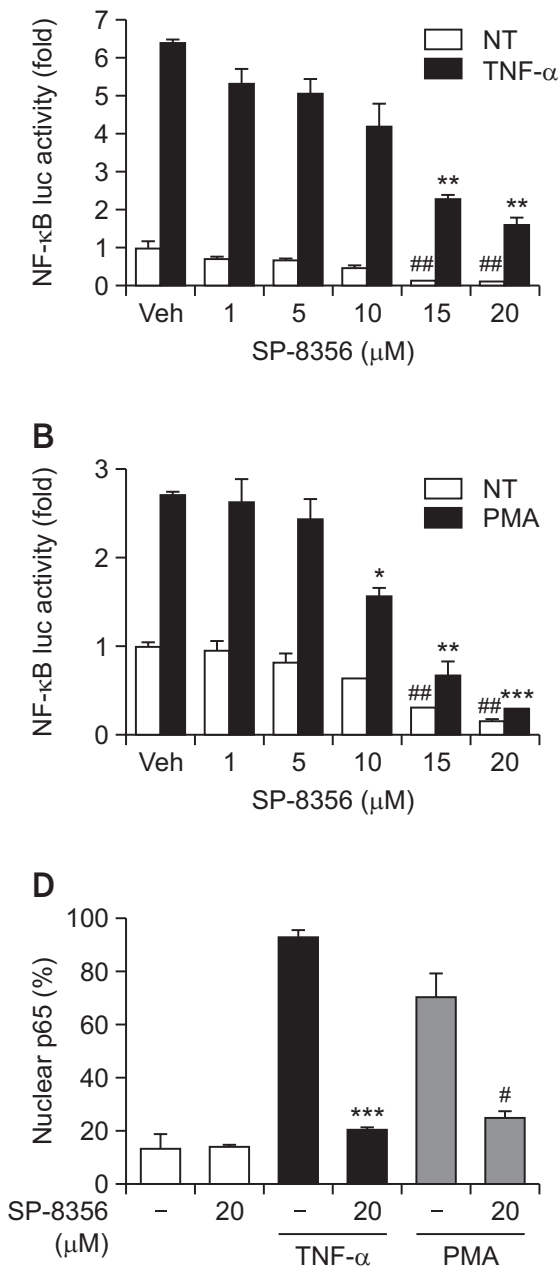

E

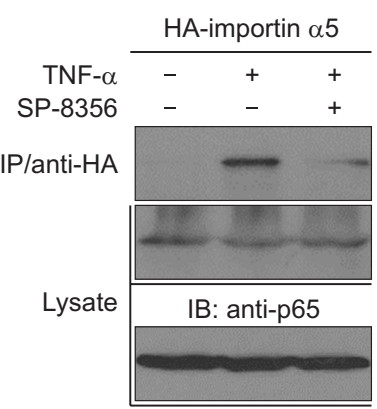

IB: anti-HA
C
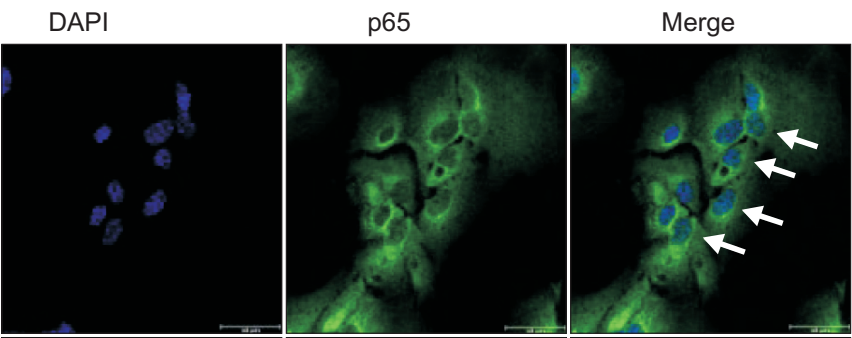

SP-8356
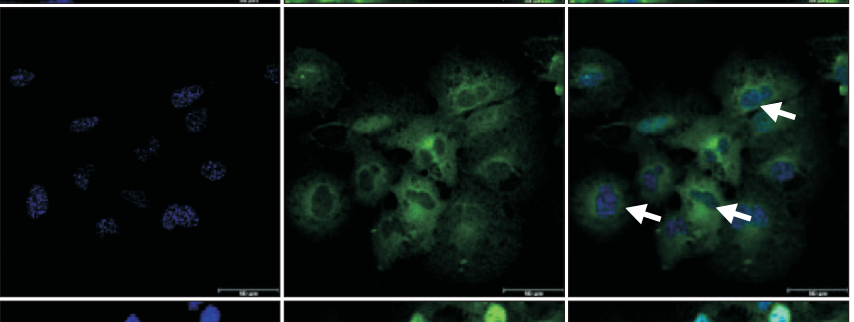

TNF- $\alpha$

PMA
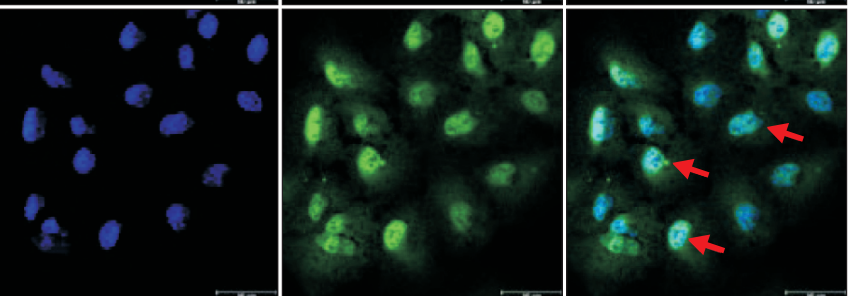

SP-8356

/TNF- $\alpha$
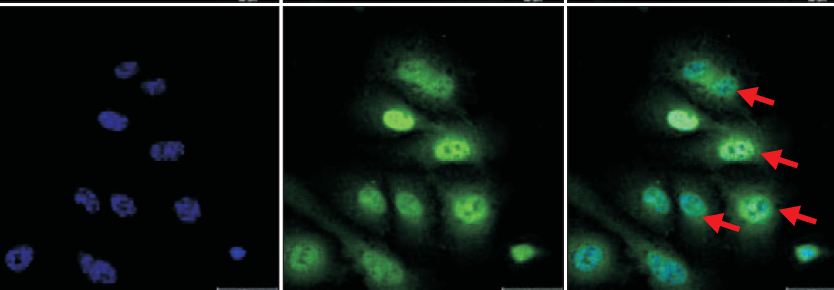

SP-8356

/PMA
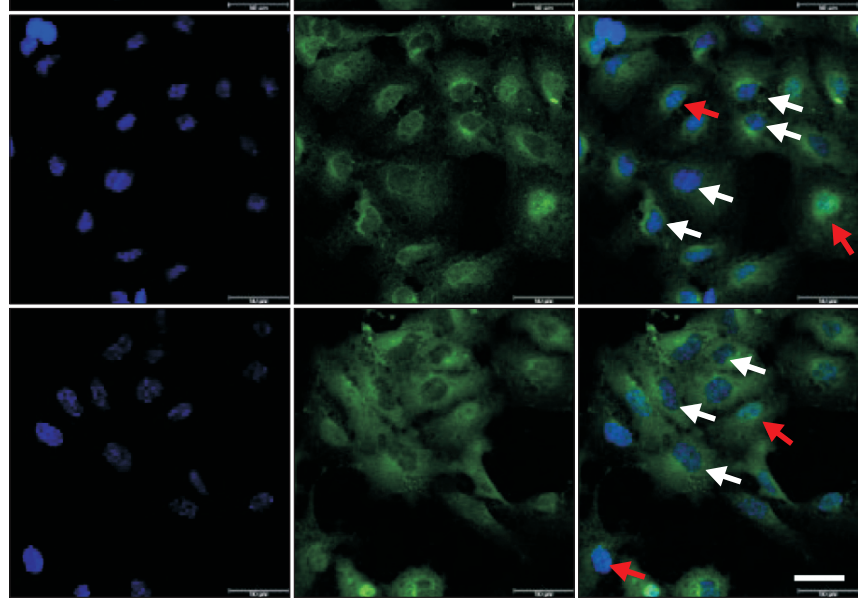

Fig. 5. SP-8356 inhibits the NF-kB signaling pathway in Huh-7 cells. (A, B) Treatment with SP-8356 reduced TNF- $\alpha$ - and PMA-stimulated $\mathrm{NF}-\kappa \mathrm{B}$ activity. Cells were transiently transfected with an NF-KB-luciferase reporter gene construct. After $18 \mathrm{~h}$ of serum starvation, the cells were treated with SP-8356 for 30 min and stimulated with $10 \mathrm{ng} / \mathrm{mL}$ TNF- $\alpha$ and $1 \mu \mathrm{M}$ PMA. Cell lysates were prepared and subjected to the luciferase assay. For panel $A$, non-treated group; $F(5,6)=18.47, p<0.0014$ and TNF- $\alpha$ treated group; $F(5,6)=25.81, p<0.0006$ across SP8356 concentration. For panel $\mathrm{B}$, non-treated group; $\mathrm{F}(5,6)=25.37, p<0.0006$ and PMA treated group; $\mathrm{F}(5,6)=41.12, p<0.0001$ across $\mathrm{SP}$ 8356 concentration. (C) SP-8356 inhibits the nuclear translocation of the NF-kB p65 subunit. Huh-7 cells were serum starved for $18 \mathrm{~h}$, pretreated with $20 \mu \mathrm{M} \mathrm{SP}-8356$ for 30 min and stimulated with $10 \mathrm{ng} / \mathrm{mL}$ TNF- $\alpha$ and $1 \mu \mathrm{M}$ PMA for 30 min, and then stained with 4',6-diamidino2-phenylindole or FITC-conjugated antibodies for the subcellular localization of p65 (green). White arrows indicate cytosolic p65 and red arrows indicate nuclear p65. Scale bar=25 $\mu \mathrm{m}$. (D) Quantitation of NF-kB p65 nuclear translocation in the indicated treatment groups. Data are expressed as the percentage of cells with nuclear NF- $\kappa B$ p65 subunit. (E) Immunoprecipitation. HEK293 cells expressing HA-importin $\alpha 5$ were treated with TNF- $\alpha$ and subjected to immunoprecipitation with anti-HA antibody. Western blotting was performed with anti-p65 and anti-HA antibodies. All values are shown as means \pm SD. ${ }^{\#} p<0.05,{ }^{\#} p<0.01$ within non-treated groups and ${ }^{*} p<0.05,{ }^{* *} p<0.01,{ }^{* * *} p<0.001$ within treated groups versus Vehicle by one-way analysis of variance (ANOVA) with Bonferroni post hoc test and Students $t$-test. 

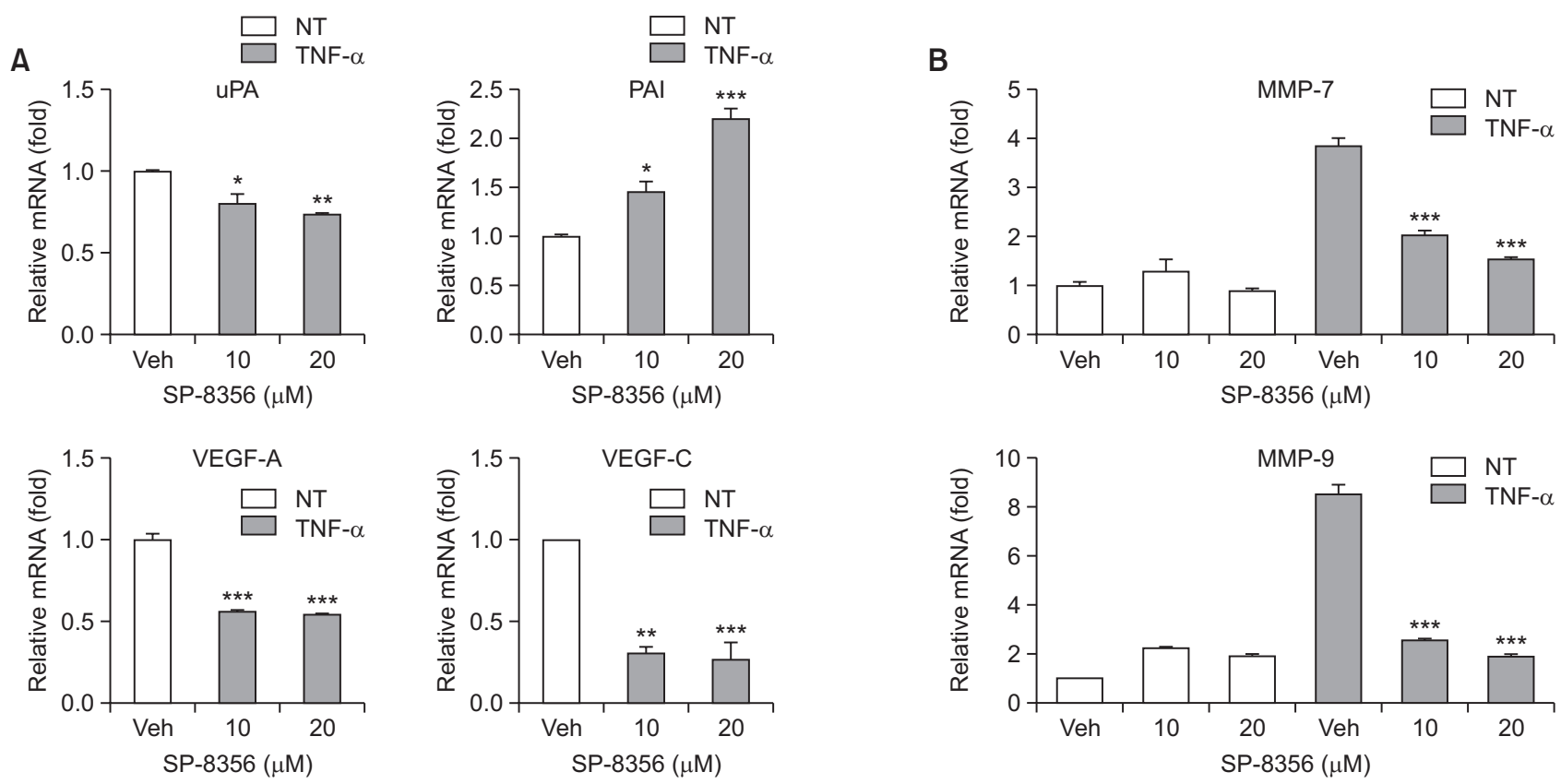

Fig. 6. SP-8356 modulates the expression of metastasis-related genes. (A) The effect of SP-8356 on relative mRNA expression levels of UPA, PAI, VEGF-A, and VEGF-C in Huh-7 cells was determined by RT-qPCR. Cells were incubated with different doses of SP-8356 for $24 \mathrm{~h}$. For uPA panel; $\mathrm{F}(2,6)=14.76, p<0.0048$, PAI panel; $\mathrm{F}(2,6)=45.27, p<0.0002$, VEGF-A panel; $\mathrm{F}(2,6)=95.49, p<0.0001$ and VEGF-C panel; $F(2,6)=37.61, p<0.0004$ across SP-8356 concentration. (B) Effect of SP-8356 on relative mRNA expression levels of MMP-7 and MMP-9. Cells were pretreated with the indicated concentrations of SP-8356 for $1 \mathrm{~h}$ and then treated with $10 \mathrm{ng} / \mathrm{mL}$ TNF- $\alpha$ for $24 \mathrm{~h}$. For TNF- $\alpha$ treated groups in MMP-7 panel; $F(2,6)=125.4, p<0.0001$ and MMP-9 panel; $F(2,6)=205.3, p<0.0001$ across SP-8356 concentration. All values are shown as means \pm SD. ${ }^{*} p<0.05,{ }^{* *} p<0.01,{ }^{* *} p<0.001$ within treated groups versus Vehicle by one-way analysis of variance (ANOVA) with Bonferroni post hoc test.

rivatives, SP-8356, most significantly suppressed cancer cell proliferation. Therefore, SP-8356 was selected as a candidate to treat liver cancer. The inhibitory effect of SP-8356 on liver cancer growth was mediated by its mild cytotoxicity through the induction of apoptosis.

ERK1/2 signaling plays a central role in cancer proliferation because many mitogens and growth factors transmit their signals through ERK1/2 (Chambard et al., 2007; Min et al., 2011; Plotnikov et al., 2011). One of the critical steps in the transmission of ERK1/2 signals is the nuclear translocation of ERK1/2 to induce gene expression for cell growth (Flores and Seger, 2013; Plotnikov et al., 2015; Ranjan et al., 2018). SP. 8356 inhibits the nuclear translocation of ERK1/2, followed by the suppression of SRE activity, a downstream target of ERK that seems to contribute to SP-8356-mediated growth inhibition of liver cancer cells. Additionally, SP-8356 suppressed the transcriptional activity of NF-kB, a key molecular regulator of genes implicated in cell proliferation, survival, and motility in liver cancer cells (Wu et al., 2009). The nuclear translocation of $\mathrm{p} 65$ is necessary for the transmission of the NF- $\mathrm{KB}$ signal (Hoesel and Schmid, 2013). The suppression of NF-kB activation through blocking nuclear translocation of $\mathrm{p} 65$ by SP-8356 was also confirmed in liver cancer cells. Therefore, the inhibitory action of SP-8356 on liver cancer cell proliferation may be related to $\mathrm{ERK}$ and NF- $\mathrm{KB}$ regulation via blocking the nuclear translocation process.

Because NF-kB modulates expression of genes implicated in the epithelial-mesenchymal transition and metastasis (Huber et al., 2004; Min et al., 2008; Naugler and Karin, 2008), the suppression of NF-kB by SP-8356 is strongly associated with inhibiting cancer progression. Cancer metastasis starts with the entry of cancer cells from a well-confined primary tumor into the surrounding tumor-associated stroma and then into the adjacent normal tissue parenchyma (Valastyan and Weinberg, 2011). To invade the surrounding tissue, it is necessary to degrade the extracellular matrix (ECM). Matrix metalloproteases (MMPs) are important enzymes that can degrade the ECM and promote cancer cell mobility; in particular, MMP7 and MMP9 are overexpressed in liver cancer and play a central role in liver cancer metastasis (Arii et al., 1996; Yeh et al., 2012; Chen et al., 2013; Lin et al., 2017). uPA is a serine protease that converts plasminogen into plasmin, the active proteinase, cleaving ECM proteins and upregulating the expression of UPA in liver cancer (Chan et al., 2004).

Cancer cells in the stroma stimulate the formation of new blood vessels within their local microenvironment for wide dissemination into distant organs (Valastyan and Weinberg, 2011). Vascular endothelial growth factor (VEGF) plays a central role in promoting angiogenesis (Saharinen et al., 2011). VEGF expression positively correlates with the metastasis and recurrence of HCC (Yao et al., 2005). The mRNA expression of these genes was significantly suppressed by SP-8356 in a dose-dependent manner. Interestingly, the mRNA level of PAI was dramatically increased by SP-8356. PAI binds to the uPA-urokinase receptor complex and induces endocytosis, followed by complex degradation. Through this process, the functions of the uPA-urokinase receptor complex, such as the activation of latent growth factors and pro-MMP, was 
A
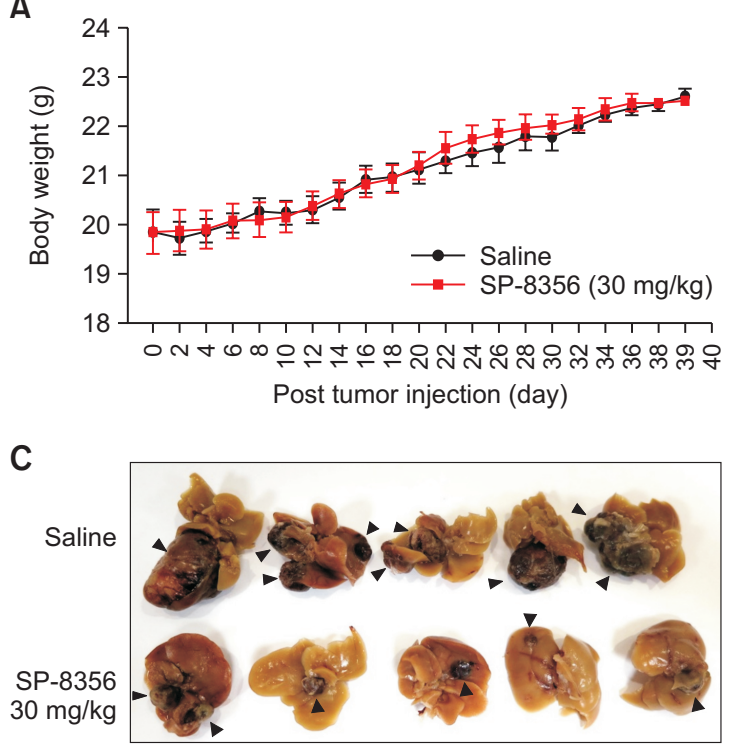

B

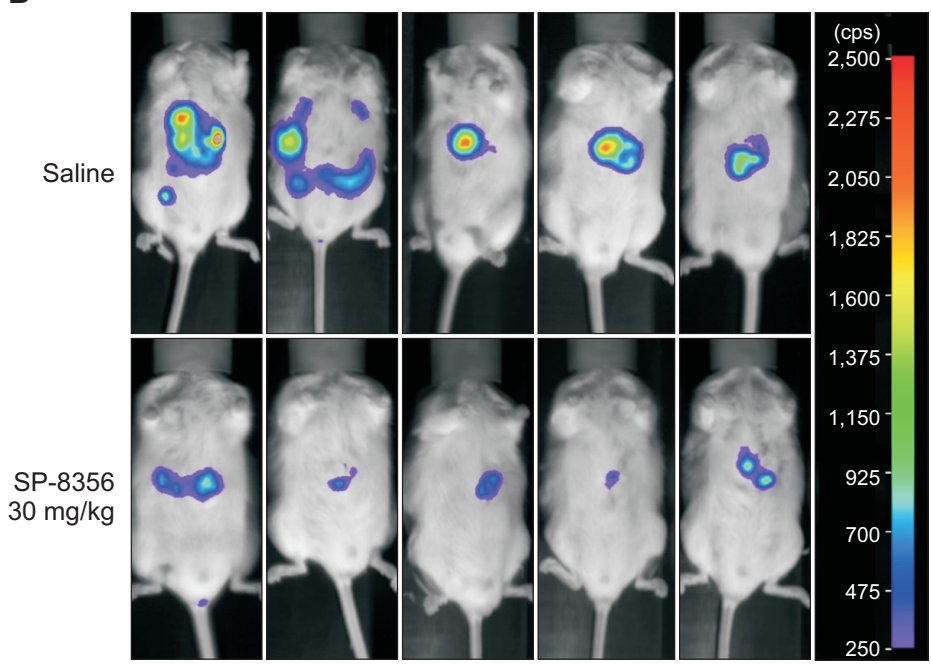

Fig. 7. SP-8356 decreases tumor growth in an orthotopic xenograft model. (A) Weight change curves after cell graft. (B) In vivo luminescence imaging. After surgical implantation of Huh-7 cells into livers of SCID mice, $30 \mathrm{mg} / \mathrm{kg} \mathrm{SP-8356}$ or saline was administered intraperitoneally every day. On 40 day after injection, the anesthetized mice were peritoneally injected with luciferin and subjected to in vivo imaging. The signaling intensity was used as a quantitative indicator. (C) Isolated liver from sacrificed mice after perfusion with PBS and $4 \%$ paraformaldehyde solution.

suppressed (Ulisse et al., 2009). Therefore, the regulation of genes implicated in cancer metastasis by SP-8356 is a possible mechanism to prevent liver cancer metastasis. Unfortunately, we could not determine the anti-metastatic activity in the SP-8356 orthotopic xenograft model with Huh-7 cells; however, its anti-proliferation activity was confirmed by tumor mass. Because Huh-7 is a relatively low metastatic cell line (Tong et al., 2017), the cells did not spread, even in the intrahepatic area. An animal model using highly metastatic liver cancer cells may help to elucidate the anti-metastatic activity of SP-8356 as demonstrated in breast cancer cells (Mander et al., 2019).

In summary, this study demonstrated that SP-8356 exerts an inhibitory effect on liver cancer cell growth and motility by regulating apoptosis- and metastasis-associated gene expression. The mechanisms of SP-8356 related to cell growth and migration may result from its regulation of signaling pathways involving NF-kB and MAPK by inhibiting their nuclear translocation. In conclusion, SP-8356 may inhibit liver cancer progression by modulating multiple target molecules in cancer cell activation mechanisms.

\section{CONFLICT OF INTEREST}

The authors declare there is no conflict of interest.

\section{ACKNOWLEDGMENTS}

This work was supported by Korea Research Foundation Grants (NRF-2019R1A2C1090051) funded by the Ministry of Science, ICT, and Future Planning, Republic of Korea.

\section{REFERENCES}

Arii, S., Mise, M., Harada, T., Furutani, M., Ishigami, S., Niwano, M., Mizumoto, M., Fukumoto, M. and Imamura, M. (1996) Overexpression of matrix metalloproteinase 9 gene in hepatocellular carcinoma with invasive potential. Hepatology 24, 316-322.

Bruix, J. and Sherman, M.; American Association for the Study of Liver Diseases (2011) Management of hepatocellular carcinoma: an update. Hepatology 53, 1020-1022.

Chaffer, C. L. and Weinberg, R. A. (2011) A perspective on cancer cell metastasis. Science 331, 1559.

Chambard, J. C., Lefloch, R., Pouyssëgur, J. and Lenormand, P. (2007) ERK implication in cell cycle regulation. Biochim. Biophys. Acta 1773, 1299-1310.

Chan, C. F., Yau, T. O., Jin, D. Y., Wong, C. M., Fan, S. T. and Ng, I. O. (2004) Evaluation of nuclear factor-kappaB, urokinase-type plasminogen activator, and $\mathrm{HBx}$ and their clinicopathological significance in hepatocellular carcinoma. Clin. Cancer Res. 10, 41404149.

Chen, L., Li, M., Li, Q., Wang, C. J. and Xie, S. Q. (2013) DKK1 promotes hepatocellular carcinoma cell migration and invasion through $\beta$-catenin/MMP7 signaling pathway. Mol. Cancer 12, 157.

Choi, I. Y., Lim, J. H., Hwang, S., Lee, J. C., Cho, G. S. and Kim, W. K. (2010) Anti-ischemic and anti-inflammatory activity of (S)-cisverbenol. Free. Radic. Res. 44, 541-551.

Coussens, L. M. and Werb, Z. (2002) Inflammation and cancer. Nature 420, 860-867.

El-Serag, H. B. and Rudolph, K. L. (2007) Hepatocellular carcinoma: epidemiology and molecular carcinogenesis. Gastroenterology 132, 2557-2576.

Flores, K. and Seger, R. (2013) Stimulated nuclear import by $\beta$-like importins. F1000Prime Rep. 5, 41.

Hoesel, B. and Schmid, J. A. (2013) The complexity of NF-kB signaling in inflammation and cancer. Mol. Cancer 12, 86.

Huber, M. A., Azoitei, N., Baumann, B., Grpnert, S., Sommer, A., Pehamberger, H., Kraut, N., Beug, H. and Wirth, T. (2004) NF-kappaB is essential for epithelial-mesenchymal transition and metastasis in a model of breast cancer progression. J. Clin. Invest. 114, 569-581.

Je, Y., Schutz, F. A. B. and Choueiri, T. K. (2009) Risk of bleeding with 
vascular endothelial growth factor receptor tyrosine-kinase inhibitors sunitinib and sorafenib: a systematic review and meta-analysis of clinical trials. Lancet Oncol. 10, 967-974.

Ju, C., Song, S., Hwang, S., Kim, C., Kim, M., Gu, J., Oh, Y. K., Lee, K., Kwon, J., Lee, K., Kim, W. K. and Choi, Y. (2013) Discovery of novel (1S)-(-)-verbenone derivatives with anti-oxidant and antiischemic effects. Bioorg. Med. Chem. Lett. 23, 5421-5425.

Kuo, C. F., Su, J. D., Chiu, C. H., Peng, C. C., Chang, C. H., Sung, T. Y., Huang, S. H., Lee, W. C. and Chyau, C. C. (2011) Anti-inflammatory effects of supercritical carbon dioxide extract and its isolated carnosic acid from Rosmarinus officinalis leaves. J. Agric. Food Chem. 59, 3674-3685.

Li, W., Tan, D., Zenali, M. J. and Brown, R. E. (2009) Constitutive activation of nuclear factor-kappa B (NF-kB) signaling pathway in fibrolamellar hepatocellular carcinoma. Int. J. Clin. Exp. Pathol. 3, 238-243.

Lin, Y., Liu, J., Huang, Y., Liu, D., Zhang, G. and Kan, H. (2017) microRNA-489 plays an anti-metastatic role in human hepatocellular carcinoma by targeting matrix metalloproteinase-7. Transl. Oncol. 10, 211-220.

Liu, P., Cheng, H., Roberts, T. M. and Zhao, J. J. (2009) Targeting the phosphoinositide 3-kinase pathway in cancer. Nat. Rev. Drug Discov. 8, 627-644.

Llovet, J. M., Ricci, S., Mazzaferro, V., Hilgard, P., Gane, E., Blanc, J. F., De Oliveira, A. C., Santoro, A., Raoul, J. L., Forner, A., Schwartz, M., Porta, C., Zeuzem, S., Bolondi, L., Greten, T. F., Galle, P. R., Seitz, J. F., Borbath, I., Hæussinger, D., Giannaris, T., Shan, M., Moscovici, M., Voliotis, D. and Bruix, J. (2008) Sorafenib in advanced hepatocellular carcinoma. N. Engl. J. Med. 359, 378-390.

Mander, S., Kim, D. H., Thi Nguyen, H., Yong, H. J., Pahk, K., Kim, E. Y., Lee, K., Seong, J. Y., Kim, W. K. and Hwang, J. I. (2019) SP8356, a (1S)-(-)-verbenone derivative, exerts in vitro and in vivo anti-breast cancer effects by inhibiting NF-кB signaling. Sci. Rep. 9, 6595.

Marrero, C. R. and Marrero, J. A. (2007) Viral hepatitis and hepatocellular carcinoma. Arch. Med. Res. 38, 612-620.

Min, C., Eddy, S. F., Sherr, D. H. and Sonenshein, G. E. (2008) NFkappaB and epithelial to mesenchymal transition of cancer. J. Cell. Biochem. 104, 733-744.

Min, L., He, B. and Hui, L. (2011) Mitogen-activated protein kinases in hepatocellular carcinoma development. Semin. Cancer Biol. 21, 10-20.

Nakagawa, H. and Maeda, S. (2012) Inflammation- and stress-related signaling pathways in hepatocarcinogenesis. World J. Gastroenterol. 18, 4071-4081.

Naugler, W. E. and Karin, M. (2008) NF-кB and cancer-identifying targets and mechanisms. Curr. Opin. Genet. Dev. 18, 19-26.

Okusaka, T., Okada, S., Ishii, H., Nose, H., Nagahama, H., Nakasuka H., Ikeda, K. and Yoshimori, M. (1997) Prognosis of hepatocellular carcinoma patients with extrahepatic metastases. Hepatogastroenterology 44, 251-257.

Ola, M. S., Nawaz, M. and Ahsan, H. (2011) Role of Bcl-2 family proteins and caspases in the regulation of apoptosis. Mol. Cell. Biochem. 351, 41-58.

Pahk, K., Noh, H., Joung, C., Jang, M., Song, H. Y., Kim, K. W., Han, K., Hwang, J. I., Kim, S. and Kim, W. K. (2019) A novel CD147 inhibitor, SP-8356, reduces neointimal hyperplasia and arterial stiffness in a rat model of partial carotid artery ligation. J. Transl. Med. $17,274$.

Pikarsky, E., Porat, R. M., Stein, I., Abramovitch, R., Amit, S., Kasem S., Gutkovich-Pyest, E., Urieli-Shoval, S., Galun, E. and BenNeriah, Y. (2004) NF-kappaB functions as a tumour promoter in inflammation-associated cancer. Nature 431, 461-466.

Plotnikov, A., Flores, K., Maik-Rachline, G., Zehorai, E., Kapri-Pardes, E., Berti, D. A., Hanoch, T., Besser, M. J. and Seger, R. (2015) The nuclear translocation of ERK1/2 as an anticancer target. Nat.
Commun. 6, 6685

Plotnikov, A., Zehorai, E., Procaccia, S. and Seger, R. (2011) The MAPK cascades: signaling components, nuclear roles and mechanisms of nuclear translocation. Biochim. Biophys. Acta 1813, 16191633.

Poddar, N., Ramlal, R., Ravulapati, S., Devlin, S. M., Gadani, S., Vidal, C. I., Cao, D., Befeler, A. S. and Lai, J. (2017) Extrahepatic metastasis of hepatocellular carcinoma arising from a hepatic adenoma without concurrent intrahepatic recurrence. Curr. Oncol. 24, e333e336.

Ranjan, A., Iyer, S. V., Ward, C., Link, T., Diaz, F. J., Dhar, A., Tawfik, O. W., Weinman, S. A., Azuma, Y., Izumi, T. and Iwakuma, T. (2018) MTBP inhibits the Erk1/2-Elk-1 signaling in hepatocellular carcinoma. Oncotarget 9, 21429-21443.

Saharinen, P., Eklund, L., Pulkki, K., Bono, P. and Alitalo, K. (2011) VEGF and angiopoietin signaling in tumor angiogenesis and metastasis. Trends Mol. Med. 17, 347-362.

Siegel, R. L., Miller, K. D. and Jemal, A. (2018) Cancer statistics, 2018. CA Cancer J. Clin. 68, 7-30.

Singh, A. K., Kumar, R. and Pandey, A. K. (2018) Hepatocellular Carcinoma: causes, mechanism of progression and biomarkers. Curr. Chem. Genom. Transl. Med. 12, 9-26.

Tong, R., Yang, B., Xiao, H., Peng, C., Hu, W., Weng, X., Cheng, S., Du, C., Lv, Z., Ding, C., Zhou, L., Xie, H., Wu, J. and Zheng, S. (2017) KCTD11 inhibits growth and metastasis of hepatocellular carcinoma through activating Hippo signaling. Oncotarget $\mathbf{8}$, 37717-37729.

Torre, L. A., Bray, F., Siegel, R. L., Ferlay, J., Lortet-Tieulent, J. and Jemal, A. (2015) Global cancer statistics. CA Cancer J. Clin. 2012. 65, 87-108.

Tung-Ping Poon, R., Fan, S. T. and Wong, J. (2000) Risk factors, prevention, and management of postoperative recurrence after resection of hepatocellular carcinoma. Ann. Surg. 232, 10-24.

Uchino, K., Tateishi, R., Shiina, S., Kanda, M., Masuzaki, R., Kondo, Y., Goto, T., Omata, M., Yoshida, H. and Koike, K. (2011) Hepatocellular carcinoma with extrahepatic metastasis: clinical features and prognostic factors. Cancer 117, 4475-4483.

Uka, K., Aikata, H., Takaki, S., Shirakawa, H., Jeong, S. C., Yamashina, K., Hiramatsu, A., Kodama, H., Takahashi, S. and Chayama, K. (2007) Clinical features and prognosis of patients with extrahepatic metastases from hepatocellular carcinoma. World J. Gastroenterol. 13, 414-420.

Ulisse, S., Baldini, E., Sorrenti, S. and D'armiento, M. (2009) The urokinase plasminogen activator system: a target for anti-cancer therapy. Curr. Cancer Drug Targets 9, 32-71.

Valastyan, S. and Weinberg, R. A. (2011) Tumor metastasis: molecular insights and evolving paradigms. Cell 147, 275-92.

Wang, J., Huang, Q. and Chen, M. (2003) The role of NF-kappaB in hepatocellular carcinoma cell. Chin. Med. J. 116, 747-752.

Wu, J. M., Sheng, H., Saxena, R., Skill, N. J., Bhat-Nakshatri, P., Yu, M., Nakshatri, H. and Maluccio, M. A. (2009) NF-kappaB inhibition in human hepatocellular carcinoma and its potential as adjunct to sorafenib based therapy. Cancer Lett. 278, 145-155.

Yao, D. F., Wu, X. H., Zhu, Y., Shi, G. S., Dong, Z. Z., Yao, D. B., Wu, W., Qiu, L. W. and Meng, X. Y. (2005) Quantitative analysis of vascular endothelial growth factor, microvascular density and their clinicopathologic features in human hepatocellular carcinoma. Hepatobiliary Pancreat. Dis. Int. 4, 220-226.

Yeh, C. B., Hsieh, M. J., Hsieh, Y. H., Chien, M. H., Chiou, H. L. and Yang, S. F. (2012) Antimetastatic effects of norcantharidin on hepatocellular carcinoma by transcriptional inhibition of MMP-9 through modulation of NF-kB activity. PLoS ONE 7, e31055

Zhu, Y. J., Zheng, B., Wang, H. Y. and Chen, L. (2017) New knowledge of the mechanisms of sorafenib resistance in liver cancer. Acta Pharmacol. Sin. 38, 614-622. 